\title{
Cefixime and ornidazole combination induced fixed drug eruption: a case report
}

\author{
Sakthibalan Murugesan, Gerard Marshall Raj, Mangaiarkkarasi Adhimoolam*
}

Department of Pharmacology, Sri Venkateshwaraa Medical College Hospital \& Research Centre, Puducherry, India

Received: 12 November 2019

Accepted: 12 December 2019

\section{*Correspondence:}

Dr. Mangaiarkkarasi Adhimoolam,

Email: drmangaimurali@gmail.com

Copyright: () the author(s), publisher and licensee Medip Academy. This is an open-access article distributed under the terms of the Creative Commons Attribution Non-Commercial License, which permits unrestricted non-commercial use, distribution, and reproduction in any medium, provided the original work is properly cited.

\begin{abstract}
Cefixime, a third generation cephalosporin and ornidazole, a nitroimidazole is used for a wide variety of conditions like urinary tract infections, otitis media, pharyngitis, uncomplicated gonorrhea and anaerobic infections. Fixed drug eruption (FDE) is commonly associated with anticonvulsants, antimicrobials and NSAIDs. Here we report a case of a rare cefixime and ornidazole combination induced fixed drug eruption. A 39 year old male developed hyperpigmented patches over both forearms and left thigh after consuming fixed dose combination of cefixime and ornidazole tablet for the treatment of urinary tract infection.
\end{abstract}

Keywords: Cefixime, Ornidazole, fixed dose combination, Fixed drug eruption, Hyper-pigmented patches

\section{INTRODUCTION}

Fixed drug eruption (FDE) is a specific cutaneous drug reaction which characteristically recurs in the same location after re-exposure to the same or related medications. The skin lesions manifest as either generalized non-bullous FDE with well-defined erythematous to violaceous round plaques or as generalized bullous FDE with vesicular or bullous lesions. ${ }^{1}$ The common sites of FDE are on the lips, trunk, hands and genitals and it usually resolves with a residual hyperpigmentation. They are responsible for about $10 \%$ of all adverse drug reactions. The common agents causing FDE are antibiotics (trimethoprim sulfamethoxazole, tetracycline, penicillin, and erythromycin) followed by nonsteroidal anti-inflammatory drugs (diclofenac sodium, aspirin, naproxen, and ibuprofen). ${ }^{2}$ Cephalosporins and nitroimidazoles are commonly used medication for a wide variety of disease states like urinary tract infections, otitis media, pharyngitis, uncomplicated gonorrhea anaerobic protozoal infections. Cefixime, a semi synthetic broad spectrum third generation cephalosporinis active against both Gram-positive and Gram-negative aerobic bacteria. It is orally effective against urinary tract infection caused by Escherichia coli and Proteus mirabilis. ${ }^{3}$ Ornidazole, a nitroimidazole, is active against a wide variety of anaerobic protozoal parasites and anaerobic bacteria. Hypersensitivity to third generation cephalosporins and nitroimidazoles has been previously reported individually.

\section{CASE REPORT}

A 39 year old male presented to the Dermatology Department of our hospital with complaints of multiple hyper-pigmented patches over both forearms and left thigh with no itching/burning sensation for the past 2 months. He did not have any systemic complaints. History revealed that symptoms developed following consuming the fixed dose combination (FDC) of cefixime and ornidazole tablet for urinary tract infection prescribed by the Surgery Department of our hospital. Past history revealed a similar kind of allergic reaction 1 year back to an antibiotic (not recalled) at the same site. 
On examination, the patient was conscious, afebrile and vitals were stable. There were no signs of anaemia, cyanosis and clubbing and the lymph nodes were normal. Local examination showed multiple, well defined, violaceous patches on both forearms and left thigh (Figure $1 \mathrm{~A}$ and $\mathrm{B})$. The genital examination was insignificant. Blood investigations were normal. Based on the clinical examination and history, the patient was diagnosed as cefixime/ornidazole combination-induced FDE. Patch test was not done as the patient did not give consent. The offending drug was stopped immediately. Patient was conservatively managed with topical corticosteroids and oral cetirizine. The lesion improved gradually in the next 15 days leaving residual hyperpigmentation. He was advised to avoid cefixime and ornidazole in future. This case was reported to the nearby adverse drug reaction monitoring centre.
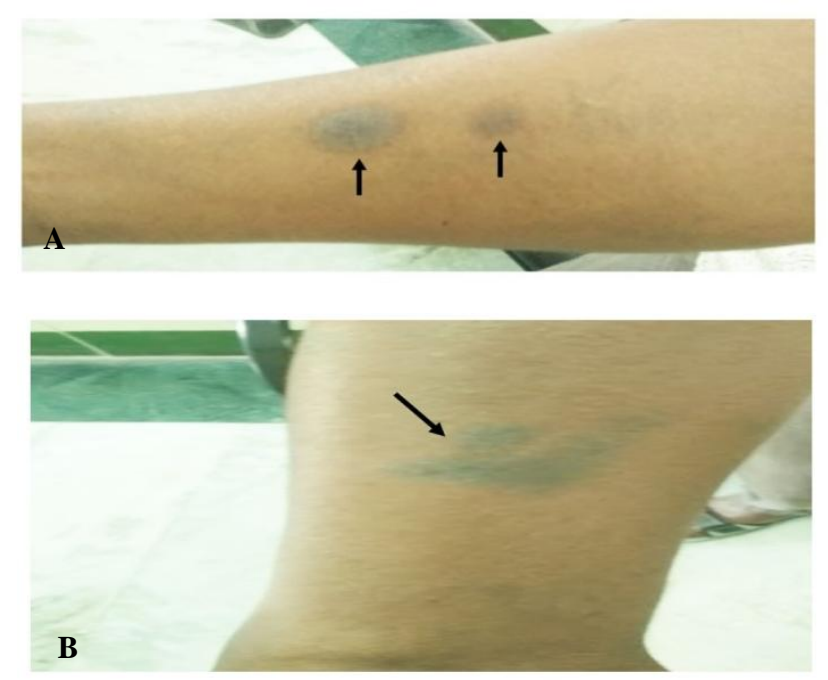

Figure 1 (A and B): The arrow indicates well defined, violaceous patches.

The Naranjo's algorithm was used to assess the causal probability of the reaction occurring due to cefixime and ornidazole. ${ }^{4}$ The following criteria were considered: There were previous conclusive reports on this reaction $(+1)$; the adverse event appeared after cefixime and ornidazole was administered $(+2)$; adverse event improved when cefixime and ornidazole was discontinued $(+1)$; adverse event reappeared when cefixime and ornidazole was re-administered (0); alternate causes that could solely have caused the reaction $(+2)$; the reaction reappeared when a placebo was given $(0)$; drug detected in the blood (or other fluids) in a concentration known to be toxic (0); the reaction was more severe when the dose was increased or less severe when the dose was decreased $(0)$; the patient had a similar reaction to cefixime and ornidazole in the previous exposure $(0)$; the adverse event confirmed by objective evidence ( 0$)$. A cumulative score of 6 was obtained suggesting a 'probable' association of reaction with cefixime and ornidazole. WHO-Uppsala Monitoring Centre causality assessment system showed that the adverse reaction was "probable/likely" with cefixime and ornidazole. ${ }^{5}$ Severity assessed by using modified Hartwig and Siegel scale and found the severity level at $3 .^{6}$

\section{DISCUSSION}

FDE is associated with sudden onset of well demarcated erythematous macules, evolving rapidly to violaceous edematous plaques; it recurs on the same site within 30 minutes to 1 day of drug administration and heals with residual pigmentation. This accounts for 16 to $21 \%$ of all cutaneous reaction. ${ }^{7}$ Morphologically, FDE initially manifests as single erythematous macule, which gradually transforms into an edematous plaque or sometimes to bullous form. The lesions are normally asymptomatic but they may be associated with pruritus and burning sensation and the lesions may be single or multiple and mostly affect the genitalia, lips, and hands with inflammatory changes and hyperpigmentation. The reactions are known as "fixed" as recurrent lesions occur at the original region following exposure to the same suspected drugs (re-challenge) and the lesion occur more rapidly than the previous exposure as it occurred in our case. The healing happens spontaneously after few days to weeks after the offending drug is discontinued leaving a hyperpigmented patch. ${ }^{8}$

FDE is proposed to be a delayed-type hypersensitivity reaction but still the exact mechanism is uncertain. The major causal factor in the development of localized tissue damage could be due to the activation of $\mathrm{CD}^{+} \mathrm{T}$ cells which retain the immunologic memory in the lesions. The immunologic memory retained can trigger the lesion but it is not sufficient enough to cause extensive tissue damage. Moreover, the $\mathrm{CD}^{+} \mathrm{T}$ cells are involved in the latter phase of lesion progress and get activated on rechallenge. $^{7,8}$

FDE has four stages which include resting phase, drug intake phase, acute evolving phase and resolution phase. Histopathologically, FDE is characterised by marked, basal cell, hydropic degeneration with pigmentary incontinence. Epidermis and dermis shows scattered keratinocyte necrosis with eosinophilic cytoplasm and pyknotic nucleus, lymphocytes, histiocytes and neutrophils. ${ }^{9}$ The peak incidence is between 21 to 40 years of age with high predilection for males compared to females. ${ }^{10}$

FDC of antibiotics have also shown to cause FDE. ${ }^{11}$ Most of FDCs available in the market is usually irrational combination of drugs which are prescribed to get faster response with incomplete and improper diagnosis. These FDCs are consumed as over-the-counter medications. ${ }^{12}$ Assessment of safety and rationale of antibacterial fixeddose combinations in the private sector in Latin American countries reported that the majority of antibacterial FDCs lacked therapeutic benefit. ${ }^{13}$ The FDC of cefixime and ornidazole is also an irrational combination used for many infectious conditions. Consumption of unsafe antibacterial 
and those antibiotics lacking sufficient therapeutic benefit is likely to contribute antibacterial resistance and ADRs.

Among the irrational FDCs banned in India recently, the antibiotic combinations accounted for $19 \% .{ }^{14}$ Antibiotic resistance is of increasing concern worldwide, but initiatives to curtail inappropriate use should be improved. Despite repeated investigations into the shortcomings of some FDCs, such drugs are still being manufactured and promoted in the Indian drug market. Among the 118 antibiotic FDCs that are available in the Indian market, 80 $(68 \%)$ of them are not registered with the Central Drugs Standard Control Organisation. Studies have shown that rising sales of antibiotic combinations in India could be undermining the global efforts to limit antimicrobial resistance, due to dozens of unapproved and some risky formulations available in the market. ${ }^{15,16}$

FDE have been reported by cefixime and ornidazole individually, but to best of our knowledge this is the first case to be reported following their use as a FDC. ${ }^{17-19}$ FDE due to other antibiotic FDCs like fluoroquinolone with nitroimidazole combinations have been reported. ${ }^{20,21}$ The present case was presented to document an uncommon side effect of a commonly prescribed FDC, particularly in India. Cross reactions can also occur with structurally similar compound like tinidazole and cephalosporin combination. Thus, our case elucidates the clinically significant but rare cutaneous reaction of cefixime and ornidazole FDC. Hence, clinicians should have a high index of suspicion and be aware of the possibility of this kind of reactions (FDE) in case of irrational prescriptions of cefixime and ornidazole combination.

\section{ACKNOWLEDGEMENTS}

We acknowledge Department of Dermatology and our Institute, Sri Venkateshwaraa Medical College Hospital and research Centre for supporting us.

Funding: No funding sources

Conflict of interest: None declared

Ethical approval: Not required

\section{REFERENCES}

1. Kavoussi H, Rezaei M, Derakhshandeh K, Moradi A, Ebrahimi A, Rashidian H, et al. Clinical Features and Drug Characteristics of Patients with Generalized Fixed Drug Eruption in the West of Iran (2005-2014). Dermatol Res Pract. 2015;2015:236703.

2. Saini R, Sharma B, Verma PK, Rani S, Bhutani G. Fixed drug eruptions: causing drugs, pattern of distribution and causality assessment in a leading tertiary care hospital. Int J Res Med Sci 2016;4(10):4356-8

3. MacDougall A. Penicillins, Cephalosporins, and Other $\beta$-Lactam Antibiotics, The Pharmacological Basics of Therapeutics: 13th edition, Goodman \& Gilman, McGraw Hill; 1989: 1023-1028.
4. Naranjo CA, Busto U, Sellars EM,Sandor P, Ruiz I, Roberts EA and Janecek E. Method for Estimating theProbability of Adverse DrugReactions. Clin Pharmacol Ther. 1981;30:239-45.

5. The use of the WHO-UMC system for standardised case causality assessment. Accessed from: https://www.who.int/medicines/areas/quality_safety/s afety_efficacy/WHOcausality_assessment.pdf.

Accessed on $5^{\text {th }}$ July 2019.

6. Hartwig SC, Siegel J and Schneider PJ. Preventability and Severity Assessment in Reporting AdverseDrug reactions. Am J Hospital Pharma. 1992;49:2229-31.

7. Greaves MW. Antihistamines. In: Wolverton SE, editor. Comprehensive Dermatologic Drug Therapy. 2nd ed. Philadelphia: Saunders, Elsevier; 2007: 391400.

8. Sehgal VN, Verma P, Bhattacharya SN. Cutaneous tuberculosis: a diagnostic dilemma. Skinmed. 2012;10(6):373-83.

9. Mizukawa Y, Yamazaki Y, Teraki Y, Hayakawa J, Hayakawa K, Nuriya H, et al. Direct evidence for interferon-gamma production by effector-memorytype intraepidermal $\mathrm{T}$ cells residing at an effector site of immunopathology in fixed drug eruption. Am J Pathol. 2002;161:1337-47.

10. Hiatt KM, Horn TD. Cutaneous toxicities of drugs. In: Elder DE, Elenitsas R, Johnson BL, Murphy GF, $\mathrm{Xu} \mathrm{X}$, editors. Levers Histopathology of the Skin. 10th ed. New Delhi: Lippincott Williams and Wilkins; 2009. pp. 311-31

11. Pai VV, Bhandari P, Kikkeri NN, Athanikar SB, Sori T Indian J Pharmacol. 2012;44(5):643-5.

12. Gautam CS, Saha L. Fixed dose drug combinations (FDCs): rational or irrational: a view point. Br J Clin Pharmacol. 2008;65(5):795-6.

13. Wirtz VJ, Mol PG, Verdijk J, Vander Stichele RH, Taxis K. Use of antibacterial fixed-dose combinations in the private sector in eight Latin American Countries between 1999 and 2009. Trop Med Int Health. 2013;18(4):416-25.

14. McGettigan P, Roderick P, Mahajan R, Kadam A, Pollock AM. Use of Fixed Dose Combination (FDC) Drugs in India: Central Regulatory Approval and Sales of FDCs Containing Non-Steroidal AntiInflammatory Drugs (NSAIDs), Metformin, or Psychotropic Drugs. PLoS Med. 2015;12(5):e1001826.

15. McGettigan P, Roderick P, Kadam A, Pollock AM. Threats to global antimicrobial resistance control: Centrally approved and unapproved antibiotic formulations sold in India. Br J Clin Pharmacol. 2019;85:59-70.

16. Shafi QN, Kumar G, Gautam V, Ray P, Malhotra S. Fixed-dose combinations of antimicrobials: a need for special attention. Indian $\mathrm{J}$ Med Microbiol. 2016;34:208-9.

17. Gupta R. Fixed drug eruption due to ornidazole. Indian J Dermatol. 2014;59(6):635-5. 
18. Choudhury D, Chakravarty P. Fixed Drug Eruption Due to Ornidazole- A Case Report. Sch J App Med Sci. 2016;4(4B):1183-6.

19. Celik IK, Buyuktiryaki B, Misirlioglu ED, Hasbek E, Kocabas CN. Fixed drug eruption related to cefixime in an adolescent case. J Allergy Clin Immunol Pract. 2018;6(5):1742-3.

20. Manchukonda RS, Ramakrishna M. Ofloxacin/ornidazole induced fixed drug eruptions: a case report. Int $\mathrm{J}$ Basic Clin Pharmacol. 2016;5(2):534-8.
21. Varma SK, Nagpure S, Misra AK, Dhanvijay P. Fixed drug eruption due to fixed dose combination: A novel case. Int J Health Allied Sci 2013;2(2):130-2.

Cite this article as: Murugesan S, Raj GM, Adhimoolam M. Cefixime and ornidazole combination induced fixed drug eruption: a case report. Int J Basic Clin Pharmacol 2020;9:211-4. 